Supporting Information

\title{
Stochastic electrochemical cytometry of human platelets via particle collision approach
}

Jihye Lee, ${ }^{\dagger}$ Zayakhuu Gerelkhuu, ${ }^{\dagger}$ Jaewoo Song,${ }^{\dagger}$ Kang Hee Seol, ${ }^{\dagger}$ Byung-Kwon Kim,,${ }^{\S}$ and Jinho Chang ${ }^{\dagger}, *$

${ }^{\dagger}$ Department of Chemistry and Research Institute for Convergence of Basic Science, Hanyang University, 222 Wangsimni-ro, Seongdong-gu, Seoul 04763, Republic of Korea Department of Laboratory Medicine, Yonsei University College of Medicine, Yonsei-ro 501, Seodaemun-gu, Seoul 03722, Republic of Korea

${ }^{\S}$ Department of Chemistry, Sookmyung Women's University, Seoul 04310, Republic of Korea 


\section{Table of Contents}

\section{Figure S1}

TEM images of the PSPs for the SPIE-IP analyses.

\section{Figure S2}

NTA results from the PSP for SPIE-IP analysis.

\section{Figure S3}

(a) $\mathrm{CVs}$ for electro-oxidation of $\left[\mathrm{Fe}(\mathrm{CN})_{6}\right]^{4-}$ measured in aqueous solutions containing various concentration of $\left[\mathrm{Fe}(\mathrm{CN})_{6}\right]^{4-}$ without any other supporting electrolytes, (b) $i_{\mathrm{ss}}$ vs. concentration of $\left[\mathrm{Fe}(\mathrm{CN})_{6}\right]^{4-}$ measured from the $\mathrm{CVs}$ in (a), and (c) simulated $\mathrm{CV}$ to fit the experimental result measured in $0.4 \mathrm{M}\left[\mathrm{Fe}(\mathrm{CN})_{6}\right]^{4}$ solutions. In the simulation, the charge transfer reaction was $\left[\mathrm{Fe}(\mathrm{CN})_{6}\right]^{3-}+\mathrm{e}^{-} \leftrightharpoons$ $\left[\mathrm{Fe}(\mathrm{CN})_{6}\right]^{4-}$ with the standard rate constant, $k^{0}=21.4 \mathrm{~cm} / \mathrm{s}$ and the transfer coefficient, $\alpha=0.5$, respectively.

\section{Figure S4}

The CAs measured in aqueous solutions with (a) $10 \mathrm{mM}$ and (b) $0.1 \mathrm{M}\left[\mathrm{Fe}(\mathrm{CN})_{6}\right]^{4-}$ when PSPs are introduced into the cells at $1.08 \mathrm{pM}$.

\section{Figure S5}

CAs measured in $0.3 \mathrm{M}\left[\mathrm{Fe}(\mathrm{CN})_{6}\right]^{4-}$ solution (a) without (b) with $1.08 \mathrm{fM} F$-HPs.

\section{Figure S6}

CA measured in $10 \mathrm{mM}\left[\mathrm{Fe}(\mathrm{CN})_{6}\right]^{4-}$ solution with $1.08 \mathrm{fM} F$-HP.

Figure S7

The size distribution of $F$-HPs estimated by SPIE-IP with three different sets of measurements (bar graphs with different colours) and that by DLS (pink line).

\section{Figure S8}

NTA analysis of the size of $F$-HPs.

Figure S9

TEM image of activated $W F$-HPs.

\section{Figure S10}

The distribution of SCDs by HP collisions as a function of the corresponding $i_{\text {drop. }}$. In this case, HP is functionalized by paraformaldehyde only.

Figure S11

TEM image of inactivated $W F$-HPs.

\section{Table S1}

All the parameters of species for the balance sheet (Figure $3 \mathrm{~b}$ ) estimated in a 0.33 $\mathrm{M}\left[\mathrm{Fe}(\mathrm{CN})_{6}\right]^{4-}$ aqueous solution with the presence of $1.08 \mathrm{pM}$ PSPs during electrooxidation of $\left[\mathrm{Fe}(\mathrm{CN})_{6}\right]^{4-}$ to $\left[\mathrm{Fe}(\mathrm{CN})_{6}\right]^{3-}$ on a Pt UME.

Table S2

Zeta potentials of $F$-HPs with their various concentrations in aqueous solutions with different concentrations of $\left[\mathrm{Fe}(\mathrm{CN})_{6}\right]^{4-}$.

Table S3

The details of $a, b$, and $c$ with the corresponding adsorption area of the particle on a UME for the simulation result shown in Figure 11. 


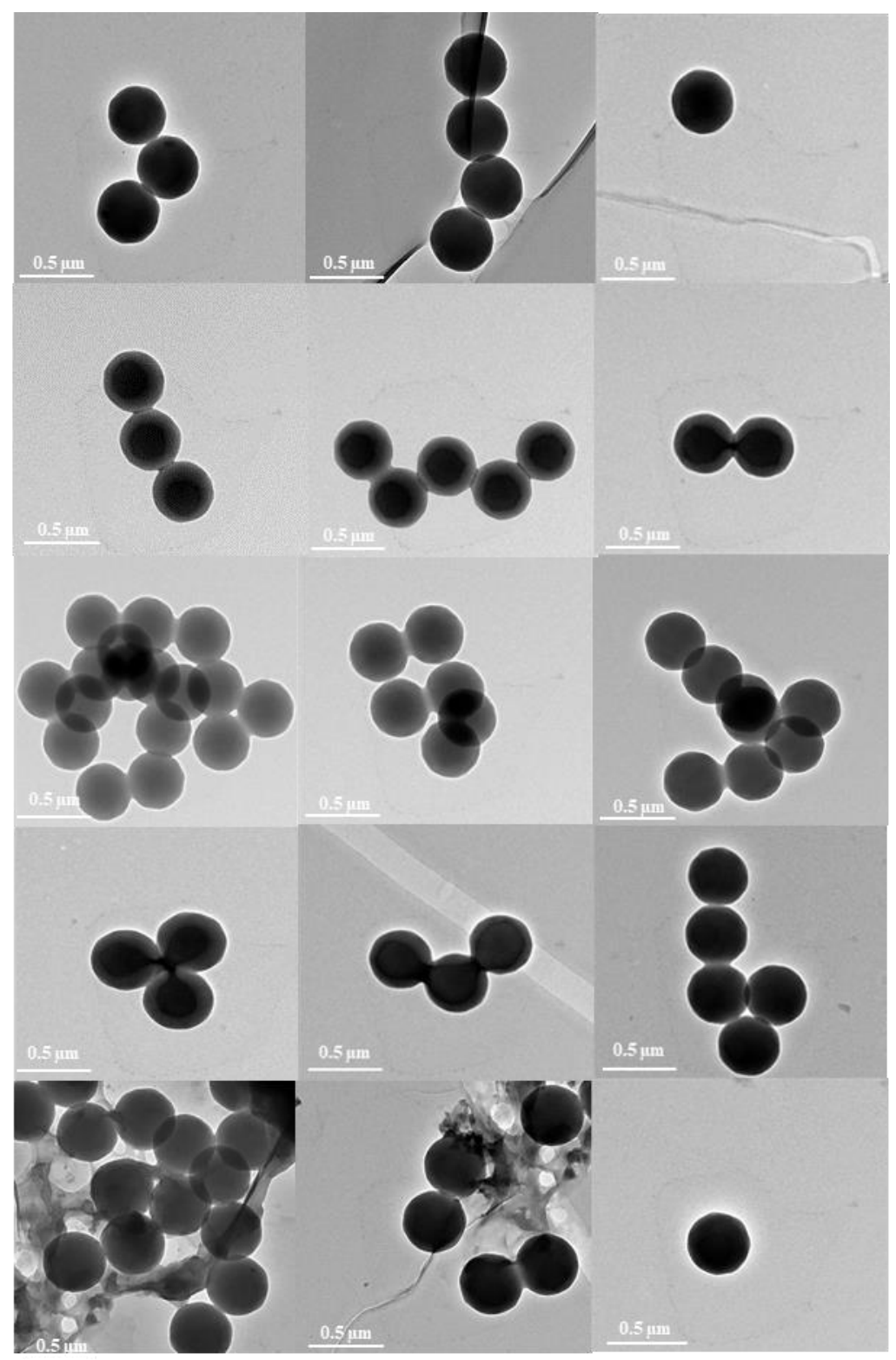

Figure S1. TEM images of the PSPs for the SPIE-IP analyses. 


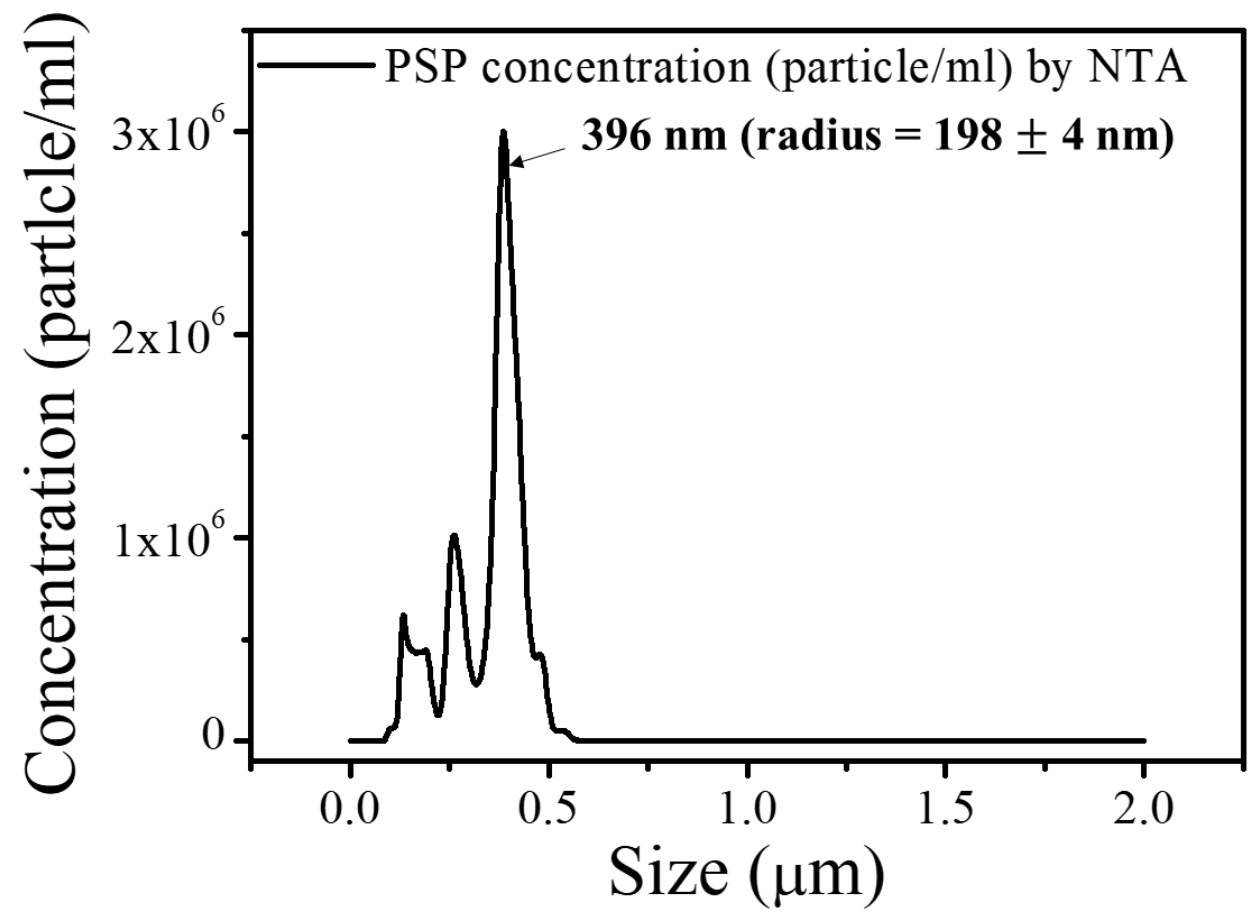

Figure S2. NTA results from the PSP for SPIE-IP analysis $(198 \pm 4 \mathbf{n m})$.
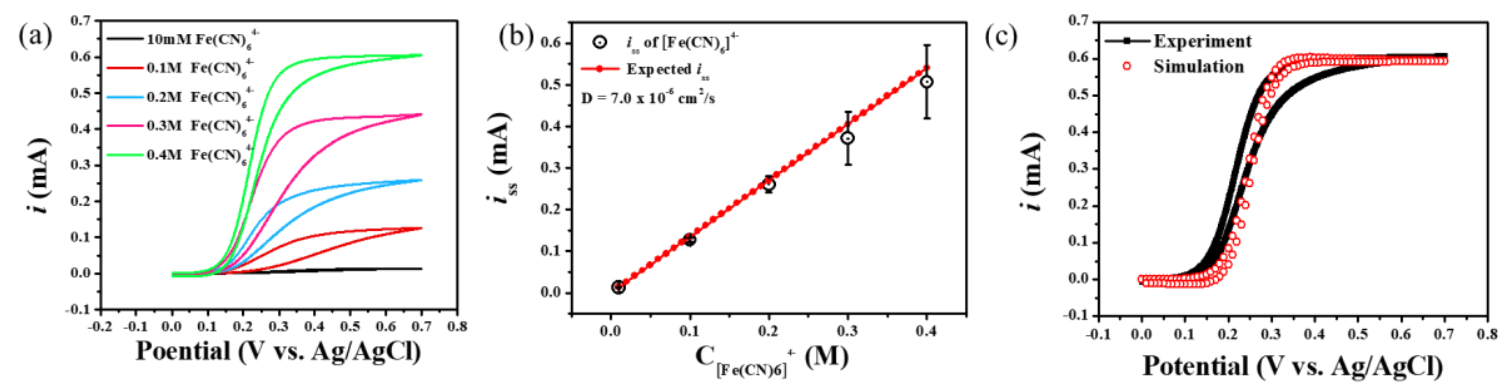

Figure S3. (a) $\mathrm{CVs}$ for electro-oxidation of $\left[\mathrm{Fe}(\mathrm{CN})_{6}\right]^{4-}$ measured in aqueous solutions containing various concentration of $\left[\mathrm{Fe}(\mathrm{CN})_{6}\right]^{4-}$ without any other supporting electrolytes, (b) $i_{\text {ss }}$ vs. concentration of $\left[\mathrm{Fe}(\mathrm{CN})_{6}\right]^{4-}$ measured from the CVs in (a), and (c) simulated CV to fit the experimental result measured in $0.4 \mathrm{M}\left[\mathrm{Fe}(\mathrm{CN})_{6}\right]^{4}$ solutions. In the simulation, the charge transfer reaction was $\left[\mathrm{Fe}(\mathrm{CN})_{6}\right]^{3-}+\mathrm{e}^{-} \leftrightharpoons\left[\mathrm{Fe}(\mathrm{CN})_{6}\right]^{4-}$ with the standard rate constant, $k^{0}=21.4 \mathrm{~cm} / \mathrm{s}$ and the transfer coefficient, $\alpha=0.5$, respectively. 
(a)

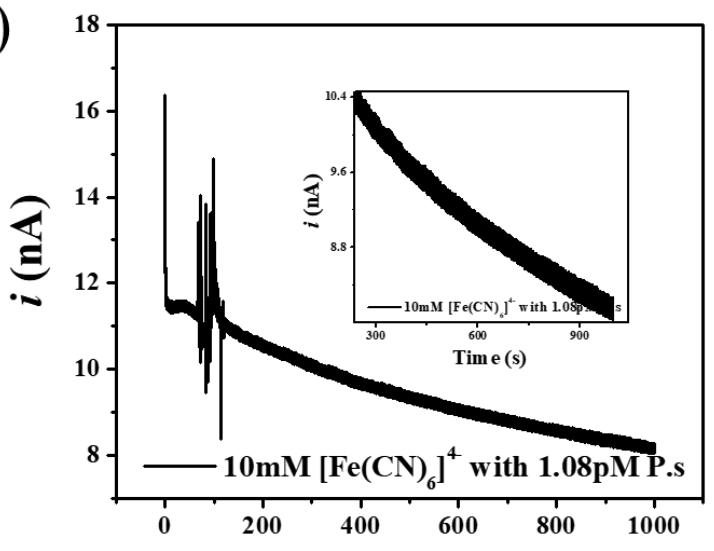

Time (s)

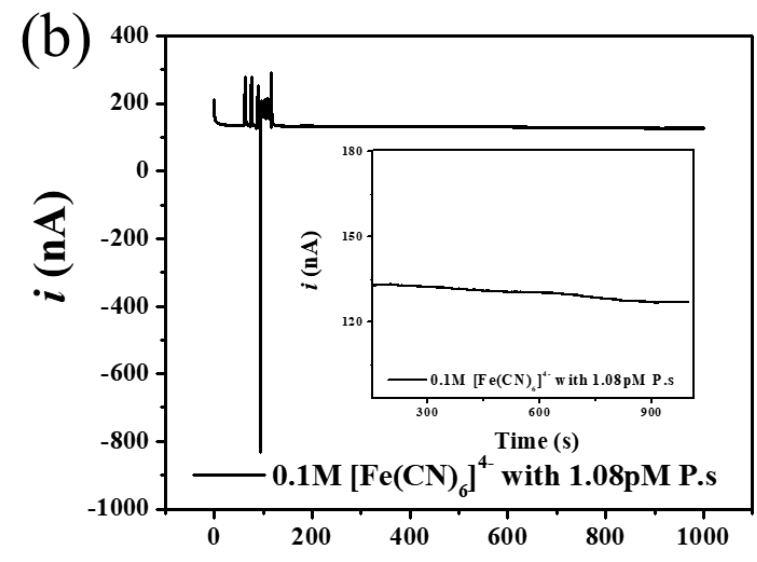

Time (s)

Figure S4. The CAs measured in aqueous solutions with (a) $10 \mathrm{mM}$ and (b) $0.1 \mathrm{M}\left[\mathrm{Fe}(\mathrm{CN})_{6}\right]^{4-}$ when PSPs are introduced into the cells at $1.08 \mathrm{pM}$.

(a)

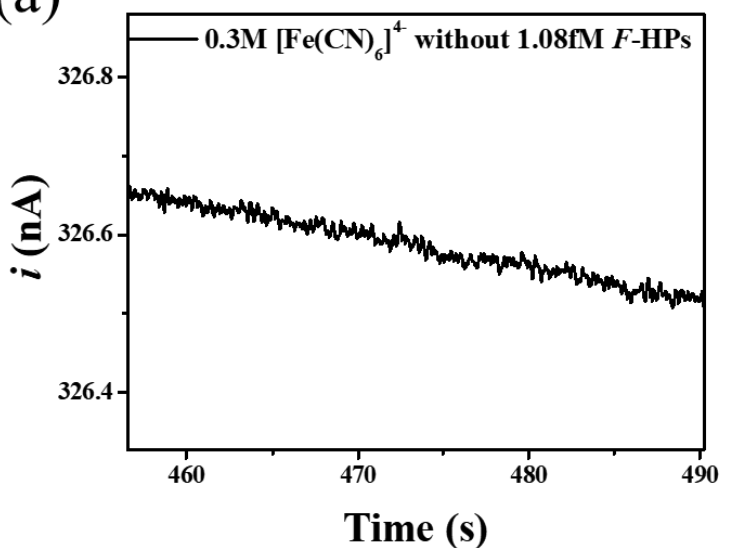

(b)

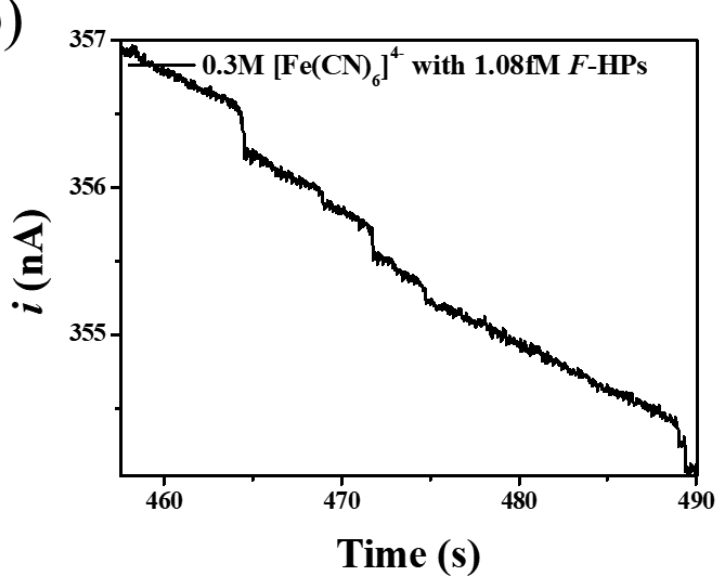

Figure S5. CAs measured in $0.3 \mathrm{M}\left[\mathrm{Fe}(\mathrm{CN})_{6}\right]^{4-}$ solution (a) without (b) with $1.08 \mathrm{fM} F$-HPs. 


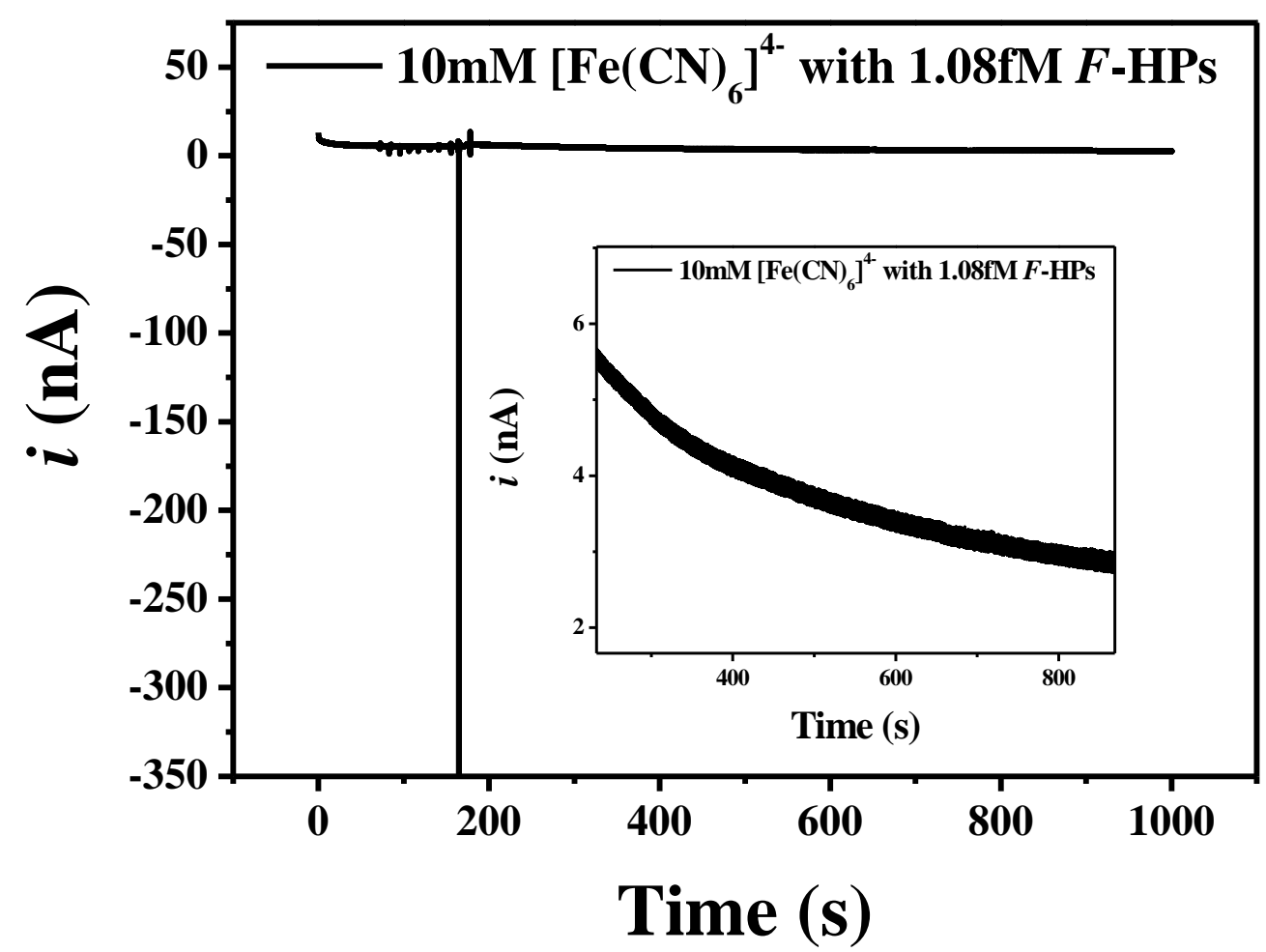

Figure S6. CA measured in $10 \mathrm{mM}\left[\mathrm{Fe}(\mathrm{CN})_{6}\right]^{4-}$ solution with $1.08 \mathrm{fM} F$-HP.

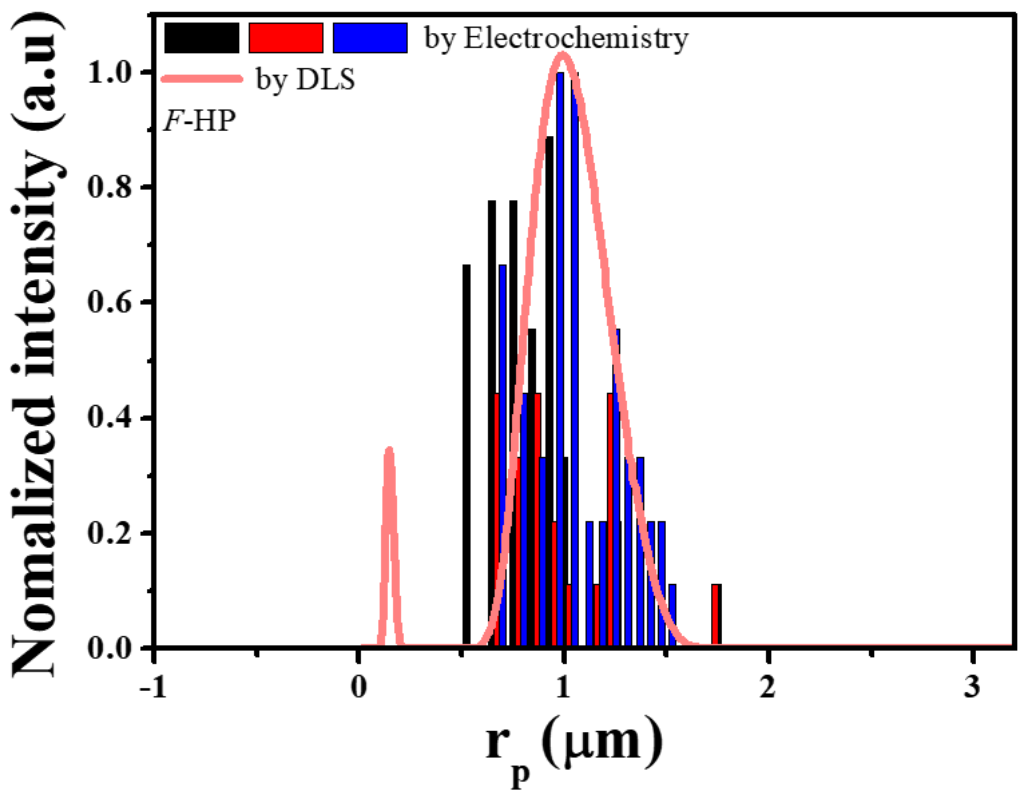

Figure S7. The size distribution of $F$-HPs estimated by SPIE-IP with the three different sets of measurements (bar graphs with different colours) and that by DLS (pink line). 


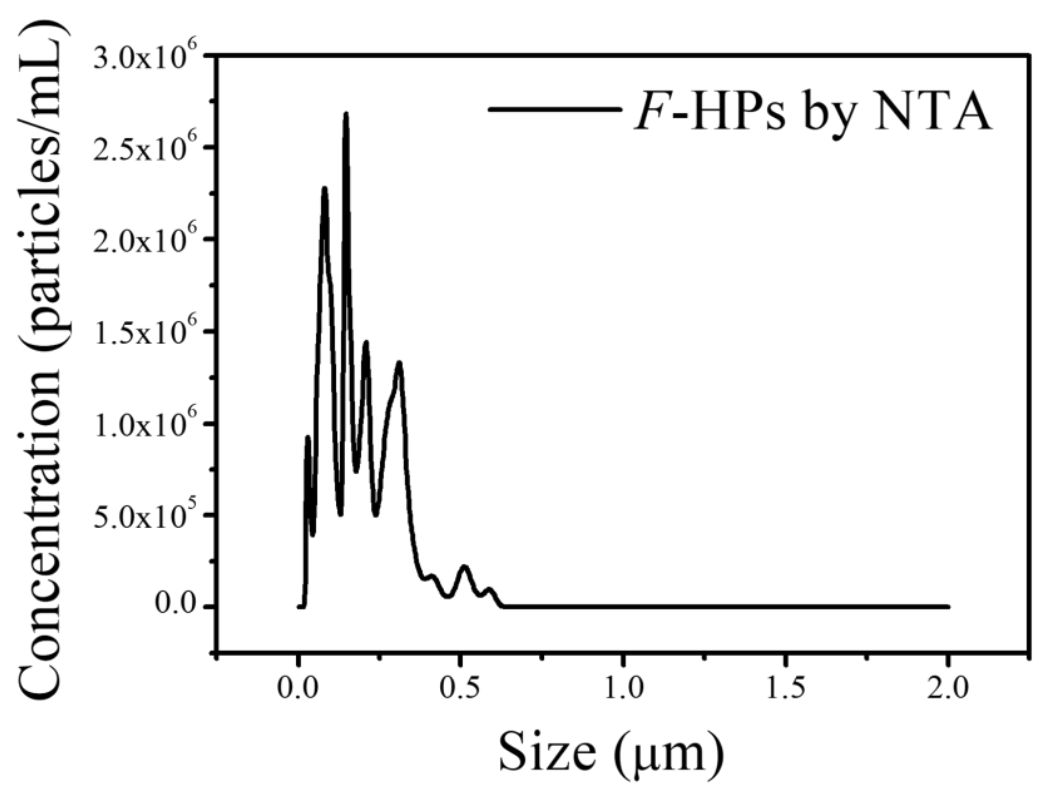

Figure S8. NTA analysis for the size of $F$-HPs. 


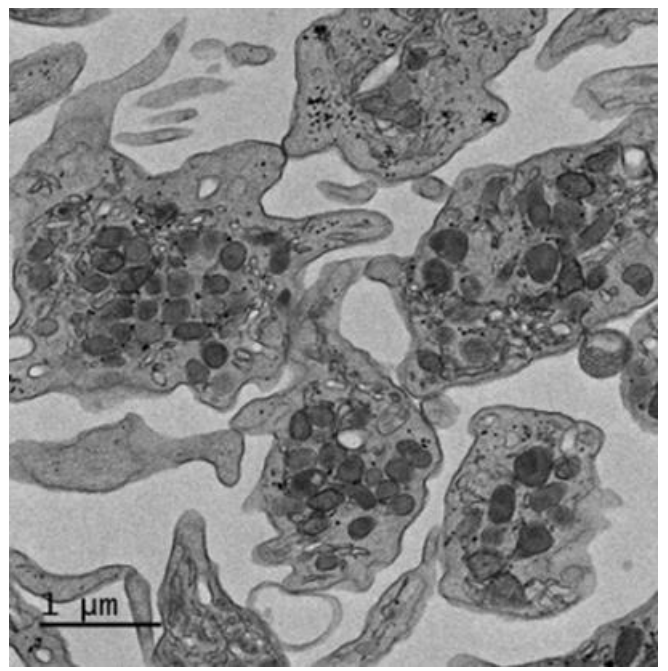

Figure S9. TEM image of activated $W F$-HPs.

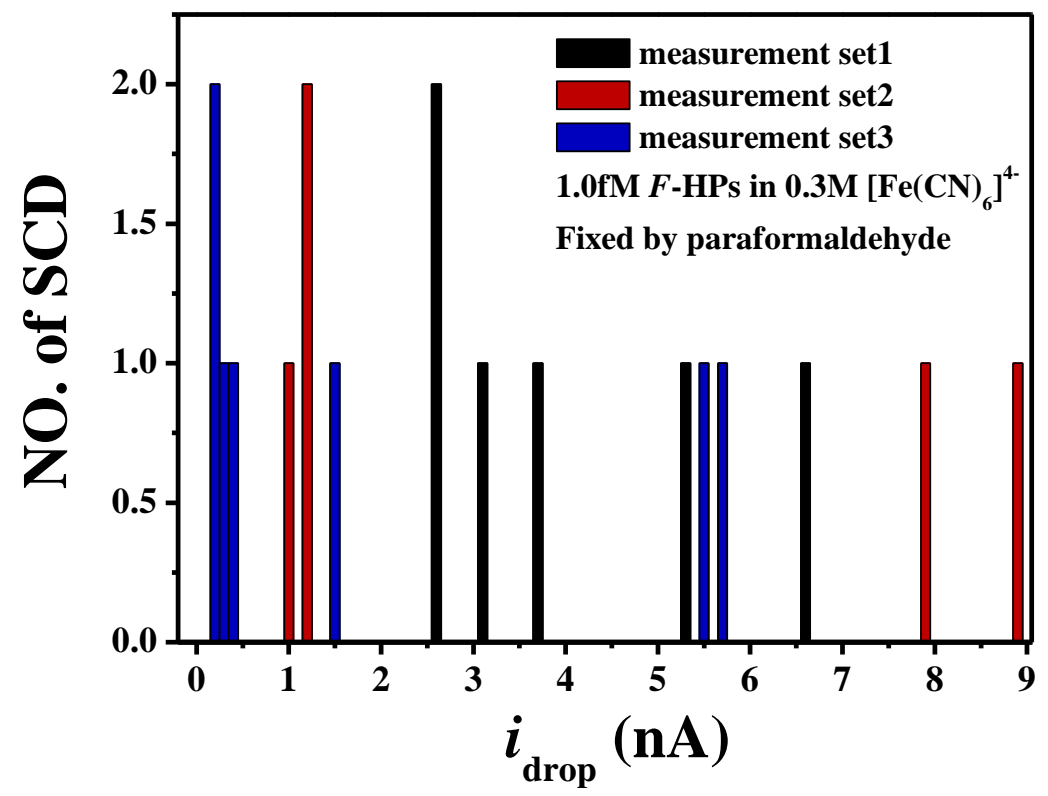

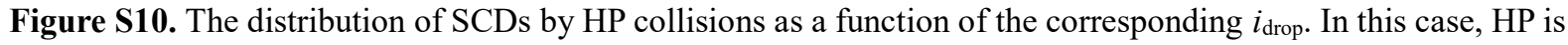
only functionalized by paraformaldehyde only. 


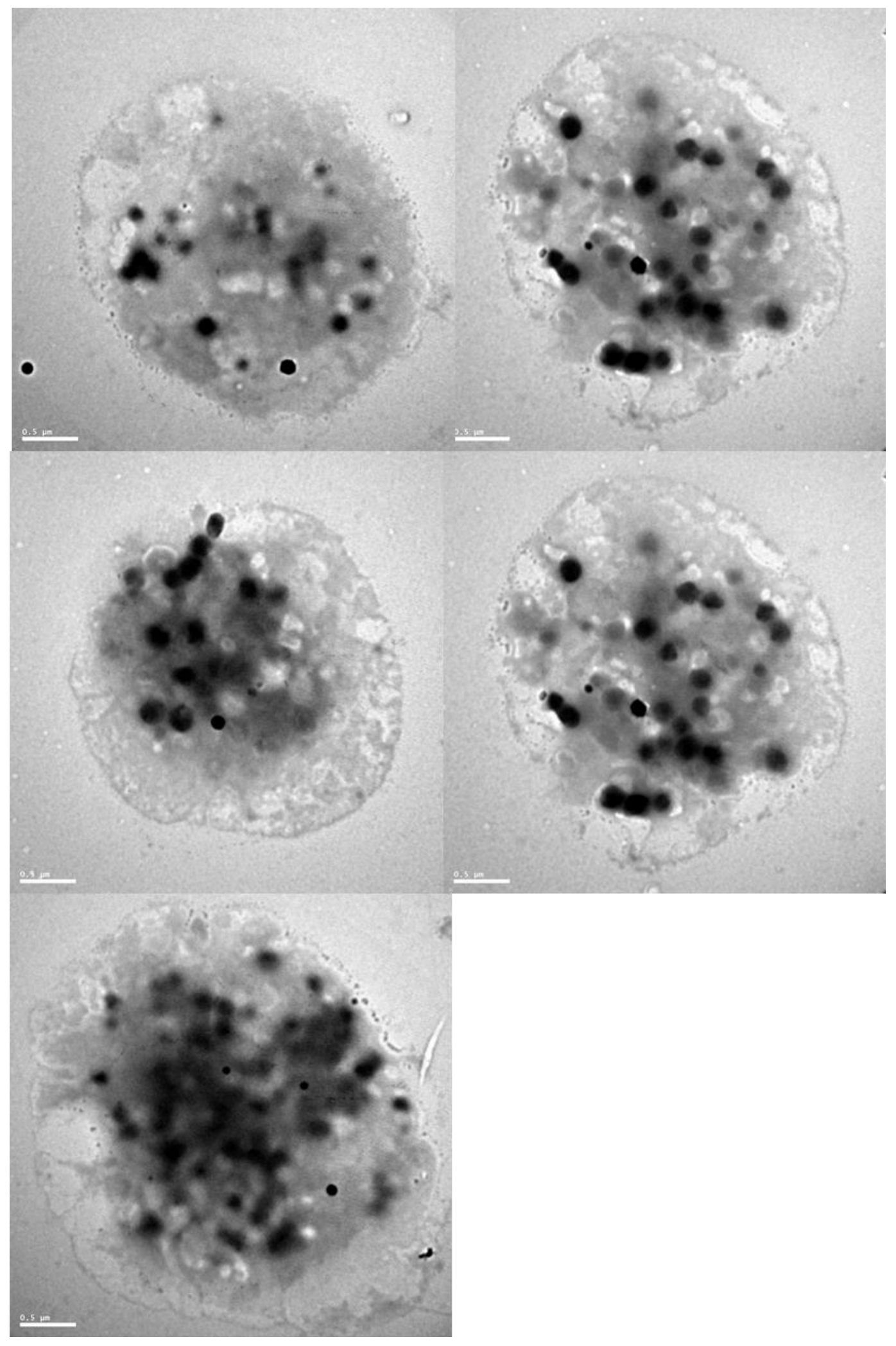

Figure S11. TEM image of inactivated $W F$-HPs 
Table S1. All the parameters of species for the balance sheet (Figure 3b) estimated in a $0.33 \mathrm{M}\left[\mathrm{Fe}(\mathrm{CN})_{6}\right]^{4-}$ aqueous solution with the presence of $1.08 \mathrm{pM}$ PSPs during electro-oxidation of $\left[\mathrm{Fe}(\mathrm{CN})_{6}\right]^{4-}$ to $\left[\mathrm{Fe}(\mathrm{CN})_{6}\right]^{3-}$ on a Pt UME.

\begin{tabular}{cccccc}
\hline Species & $D_{j}\left(\mathrm{~cm}^{2} \mathrm{~s}^{-1}\right)$ & $u_{j}\left(\mathrm{~cm}^{2} \mathrm{~s}^{-1} \mathrm{~V}^{-1}\right)$ & $C_{j}(\mathrm{M})$ & $t_{j}$ \\
\hline $\mathrm{Fe}\left(\mathrm{CN}_{6}\right)^{4-}$ & $7.0 \times 10^{-6}$ & $1.15 \times 10^{-3} 1$ & 0.3 & $6.00 \times 10^{-1}$ \\
$\mathrm{Fe}\left(\mathrm{CN}_{6}\right)^{3-}$ & $7.0 \times 10^{-6}$ & $1.05 \times 10^{-3} 1$ & 0 & 0 \\
$\mathrm{~K}^{+}$ & $1.96 \times 10^{-52}$ & $7.62 \times 10^{-4} 1$ & 1.2 & $6.00 \times 10^{-1}$ \\
$\mathrm{PSP}(-)$ & $1.26 \times 10^{-8}$ & $-1.5 \times 10^{-4} 3$ & $1.08 \times 10^{-12}$ & $6.38 \times 10^{-8}$ \\
\hline
\end{tabular}

*PSP charge was estimated to be $-125 \mathrm{mC} / \mathrm{m}^{2}$ based on the assumption that the surface density of carboxyl group (sites) on the particle surface was $1.2 \mathrm{sites} / \mathrm{nm}^{2}{ }^{4}$

*PSP diffusion coefficients were calculated using the Stokes-Einstein equation.

*Diffusion coefficients of $\mathrm{Fe}\left(\mathrm{CN}_{6}\right)^{4-}$ and $\mathrm{Fe}\left(\mathrm{CN}_{6}\right)^{3-}$ were calculated as $i_{\mathrm{ss}}$ from the $\mathrm{CV}$ in Figure S3b. 
Table S2. Zeta potentials of $F$-HPs with their various concentrations in aqueous solutions with different concentrations of $\left[\mathrm{Fe}(\mathrm{CN})_{6}\right]^{4-}$.

\begin{tabular}{|c|c|c|}
\hline $\begin{array}{c}\text { Concentration of }\left[\mathrm{Fe}(\mathrm{CN})_{6}\right]^{4-} \\
\text { (M) }\end{array}$ & $\begin{array}{l}\text { Concentration of } F \text {-HPs } \\
\text { (fM) }\end{array}$ & Zeta potential $(\mathrm{mV})$ \\
\hline & 1.08 & -34.1 \\
\hline \multirow[t]{3}{*}{$0.01 \mathrm{M}$} & 1.08 & -40.5 \\
\hline & 1.08 & -46.7 \\
\hline & 0.036 & -46.5 \\
\hline \multirow[t]{3}{*}{$0.01 \mathrm{M}$} & 0.036 & -48.5 \\
\hline & 0.036 & -50.7 \\
\hline & 0.0216 & -44.9 \\
\hline \multirow[t]{3}{*}{$0.006 \mathrm{M}$} & 0.0216 & -48.7 \\
\hline & 0.0216 & -49.8 \\
\hline & 1.08 & -41.6 \\
\hline \multirow[t]{3}{*}{ Distilled water } & 1.08 & -40.4 \\
\hline & 1.08 & -38.1 \\
\hline & 0.0216 & -46.2 \\
\hline \multirow[t]{3}{*}{ Distilled water } & 0.0216 & -46.3 \\
\hline & 0.0216 & -46.8 \\
\hline & 0.036 & -38.4 \\
\hline \multirow[t]{2}{*}{ Distilled water } & 0.036 & -38.4 \\
\hline & 0.036 & -37.2 \\
\hline
\end{tabular}


Table S3. The details of $a, b$, and $c$ with the corresponding adsorption area of the particle on an UME for the simulation result shown in Figure 11.

\begin{tabular}{ccc}
\hline \multicolumn{3}{c}{ At constant $a=1.5 \mu \mathrm{m}$} \\
\hline Adsorption area $\left(\mu \mathrm{m}^{2}\right)$ & $b(\mu \mathrm{m})$ & $c(\mu \mathrm{m})$ \\
\hline 5.0 & 1.06 & 2.12 \\
6.0 & 1.27 & 1.77 \\
7.0 & 1.49 & 1.51 \\
8.0 & 1.70 & 1.32 \\
9.0 & 1.91 & 1.18 \\
10.0 & 2.12 & 1.06 \\
11.0 & 2.34 & 0.96 \\
12.0 & 2.55 & 0.88 \\
13.0 & 2.76 & 0.82 \\
14.0 & 2.97 & 0.76 \\
15.0 & 3.18 & 0.71 \\
\hline & At constant $b=1.5 \mu \mathrm{m}$ & \\
\hline Adsorption area $\left(\mu \mathrm{m}^{2}\right)$ & $a(\mu \mathrm{m})$ & $c(\mu \mathrm{m})$ \\
\hline 5.0 & 1.06 & 2.12 \\
6.0 & 1.27 & 1.77 \\
7.0 & 1.49 & 1.51 \\
8.0 & 1.70 & 1.32 \\
9.0 & 1.91 & 1.18 \\
10.0 & 2.12 & 1.06 \\
11.0 & 2.34 & 0.96 \\
12.0 & 2.55 & 0.88 \\
13.0 & 2.76 & 0.82 \\
14.0 & 2.97 & 0.76 \\
15.0 & 3.18 & 0.71 \\
\hline & & \\
\hline & &
\end{tabular}




\section{References}

1. Bard, A. J.; Faulkner, L. R.; Leddy, J.; Zoski, C. G., Electrochemical methods: fundamentals and applications. wiley New York: 1980; Vol. 2.

2. Samson, E.; Marchand, J.; Snyder, K. A., Calculation of ionic diffusion coefficients on the basis of migration test results. Mater. and struct. 2003, 36 (3), 156-165.

3. Quevedo, I. R.; Tufenkji, N., Mobility of functionalized quantum dots and a model polystyrene nanoparticle in saturated quartz sand and loamy sand. Environ. sci. technol. 2012, 46 (8), 4449-4457.

4. Qiu, Y.; Lin, C.-Y.; Hinkle, P.; Plett, T. S.; Yang, C.; Chacko, J. V.; Digman, M. A.; Yeh, L.-H.; Hsu, J.-P.; Siwy, Z. S., Highly Charged Particles Cause a Larger Current Blockage in Micropores Compared to Neutral Particles. ACS Nano 2016, 10 (9), 8413-8422. 